\title{
Comparison of Total Phenolic Contents and Antioxidant Activities of Different Parts of the Endemic Plant Geranium ibericum subsp. jubatum
}

\section{Emriye AY ${ }^{1 *}$, Erhan Seyhan GEZEN ${ }^{1}$, Rena HÜSEYINOĞLU ${ }^{1}$}

\begin{abstract}
This paper includes the results of the first study on the phenolic content and antioxidant capacity of endemic species Geranium ibericum subsp. jubatum found in Turkey. In this study, the methanol extracts of different parts (leaf, stem, flower, and root) of the Geranium ibericum subsp. jubatum exhibited different free radical scavenging activity, total phenolic content, and antioxidant activity. The synthetic antioxidant BHT and the natural antioxidant $\alpha$-tocopherol were evaluated as a positive control and compared with methanol extracts of the plant parts. There was a positive correlation between the total phenolic content and the free radical scavenging activity in different parts of Geranium ibericum. It has been found that the highest phenolic content and antioxidant activity were found in the roots. The total phenolic content and antioxidant activity (ABTS, DPPH) showed statistically significant differences among the different parts of the G. ibericum subsp. jubatum $(\mathrm{p}<0.05)$.
\end{abstract}

Keyword: Geranium ibericum subsp. jubatum, ABTS, DPPH, antioxidant activity, total phenolic content.

\section{Endemik Tür Geranium ibericum subsp.jubatum'un Farklı Kısımlarının Toplam Fenolik İçerikleri ve Antioksidan Aktivitelerinin Karşılaştırılması}

ÖZET: Bu çalışma, endemik tür Geranium ibericum subsp. jubatum'un fenolik içeriği ve antioksidan kapasitesi üzerine yapılmış ilk çalışmanın sonuçlarını içermektedir. Çalışmada, Türkiye için endemik tür olan G.ibericum subsp. jubatum'un farklı kısımlarının (yaprak, gövde, çiçek ve kök) metanol özütlerinin toplam fenolik içerikleri ve toplam antioksidan aktiviteleri belirlenmiş ve karşılaştırma yapılmıştır. G. ibericum subsp. jubatum'un farklı kısımlarına ait metanol özütlerinin antioksidan kapasiteleri sentetik bir antioksidan olan BHT ve doğal bir antioksidan olan $\alpha$-tokoferol ile karşılaştırılmış ve sonuçlar değerlendirilmiştir. Toplam fenolik içerik ile toplam antioksidan kapasiteleri arasında pozitif bir ilişki bulunmaktadır. En yüksek fenolik içerik ve antioksidan kapasitesinin kök kısmının metanol özütüne ait olduğu bulunmuştur. Yapılan istatiksel değerlendirilmeler sonucunda G. ibericum subsp. jubatum'un farklı kısımları arasında toplam fenolik içerik ve toplam antioksidan aktiviteleri (DPPH, ABTS) yönünden önemli farklılıklar görülmüştür $(\mathrm{p}<0.05)$.

Anahtar Kelimeler: Geranium ibericum subsp. jubatum, ABTS, DPPH, antioksidan aktivitesi, toplam fenolik içerik.

\footnotetext{
1 Emriye AY (Orcid ID: 0000-0003-4611-7530), Erhan Seyhan GEZEN (Orcid ID: 0000-0003-0613-7289), Rena HÜSEYINOĞLU (Orcid ID: 0000-0002-5254-9164), Giresun University, Şebinkarahisar School of Applied Science, 28400 Giresun, Turkey

*Sorumlu Yazar/Corresponding Author: Emriye AY, e-mail: emriyeay@gmail.com

Bu çalışma Erhan Seyhan GEZEN'in Yüksek Lisans tezinden üretilmiştir. 


\section{INTRODUCTION}

The compounds found in the biological systems are divided into two broad sections: primary and secondary. Primary metabolites are chemical compounds such as carbohydrates, amino acids, proteins, and fats which are involved in the growth and development of the cell. Secondary metabolites help plants to overcome environmental challenges of survival and interaction to defeat their rivals and fend off pathogens (Ahmed et al., 2017; Siddiqui et al., 2017). These compounds protect plants, fruits, and vegetables from oxidative damage and have been used as antioxidants by people. Antioxidants protect cells against the effects of harmful free radicals (Mahdi-Pour et al., 2012; Kasangana et al., 2015).

Antioxidants are inhibitor of the process of oxidation, even at relatively small concentration and thus have diverse physiological role in the body (Kumar, 2011). There are scientific studies showing that the imbalance between excessive free radical production and antioxidant defenses in the human body may lead to the occurrence of diseases such as cancer, aging, inflammatory disorders, strokes, and diabetes. Many studies have shown that antioxidants may play an important role in preventing diseases caused by free radicals (Dai and Mumper, 2010).

The majority of the antioxidants found in foods are phenolic compounds. It is also known that antioxidants are added to foods in order to prevent off-flavors, off-odors and discolorations. Most antioxidants added to foods such as Butylated Hydroxyanisole (BHA), Butylated Hydroxytoluene (BHT), and Propyl Gallate (PG) are synthetic. Some studies revealed toxic effects of synthetic antioxidants (Kulisic et al., 2004). For this reason, researchers began to intensify their studies on plant based natural antioxidants (Aksoy et al., 2013).

An interest in functional foods and nutraceuticals has been increased day by day. The interest in functional foods and nutroceuticals requires new and healthy antioxidants produced from natural sources. The first techniques used to detect antioxidant compounds in plants are the screening of phytochemicals (Do et al., 2014).

There are many techniques used to isolate antioxidants from plants, such as soxhlet extraction, maceration, supercritical fluid extraction, subcritical water extraction, and ultrasound assisted extraction. In addition, the extraction efficiency and antioxidant activity depend not only on the method used, but also on the solvent used in the extraction (Azwanida, 2015). Polar solvents such as water, ethanol, methanol, acetone, and ethyl acetate are frequently used to extract polyphenols from plant parts. Methanol has been found to be effective in obtaining low molecular weight polyphenols. Also, the water-acetone mixture was found to be effective in obtaining high molecular weight flavanols. Phenolic compounds can be obtained from dried or fresh plants. The sample is subjected to milling before extraction to make it homogenous. The choice of the drying method is determined to affect the total phenolic content. Freeze-drying keeps the phenolic content in higher level in the plant samples compared with air drying (Mojzer et al., 2016).

The Geraniaceae family is $15-40 \mathrm{~cm}$ in length, with a long and soft hairy body. It is known that Geranium L. genus is the largest of the Geraniaceae family. Some species of this genus are used as medicinal plants in traditional medicine, and some species are used for tanning and dyeing (Serkedjieva, 1996; Kahriman et al., 2010; Zeljković et al., 2017). The chemical content of the genus Geranium spp. was investigated and it was found that the flavonoids and phenolic acids were clearly dominant (Harborne and Williams, 2002). 
Geranium ibericum subsp. jubatum which endemic to Turkey is cultivated the North-West and North-East from Turkey to the Caucasus and Iran. It is known as turnagagas among local people (Hüseyinoğlu et al., 2017).

Although there are many studies on the chemical content of other geranium species (Leucusta et al., 2005), no studies have been done with regard to the chemical content of the Geranium ibericum subsp. jubatum. This work represents the first analysis of the phenolic contents and antioxidant activities of this endemic species.

In this study, the total phenolic content and antioxidant capacity of the different parts of the endemic G. ibericum subsp. jubatum samples obtained by methanol extraction were evaluated.

\section{MATERIALS AND METHODS}

\section{Plant Material}

Geranium ibericum subsp. jubatum samples were collected from Eğribel Pass, Giresun-Turkey

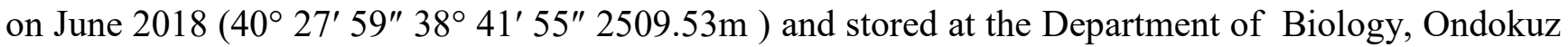
Mayıs University, Samsun.

\section{Chemicals}

Foline-Ciocalteu reagent (FCR), methanol and ethanol were obtained from Merck (Darmstadt, Germany), sodium carbonate anhydrous, gallic acid, DPPH (2,2-diphenyl-1-picrylhydrazyl), ABTS (2,2'-azinobis-(3-ethylbenzothiaziline-6-sulfonate) and BHT (Butylated Hydroxytoluene) and $\alpha$ tocopherol were purchased from Sigma-Aldrich $\mathrm{GmbH}$ (Sternheim, Germany) $\mathrm{K}_{2} \mathrm{~S}_{2} \mathrm{O}_{8}$ (potasium persulfate) was purchased from Carlo Erba.

\section{Preparation of Extracts of Plant Parts}

Flower, leaf, stem and root of the plant samples were separated, cleaned and dried in a hot-air oven at $40{ }^{\circ} \mathrm{C}$ for $48 \mathrm{~h}$. MeOH was used as the solvent for the soxhlet extraction process. For soxhlet extraction, $10 \mathrm{~g}$ samples (leaf, stem, flower and root) of different plant sections were milled in the blender and placed in the soxhlet cartridge and $250 \mathrm{~mL} \mathrm{MeOH}$ was added to the apparatus and the system was operated. After this process, the solvent mixture was filtered through and then the solvent was removed by evaporator at $40{ }^{\circ} \mathrm{C}, 175$ mbar. The extract was stored for further analysis (Chou et al., 2009; Proestos et al., 2013; Arumugam et al., 2019).

\section{Determination of Total Phenolic Compounds Content}

The amount of the total phenolic compound found in the methanolic extracts of the different parts of G. ibericum subsp. jubatum was determined by Folin-Ciocalteu reagent (FCR) method. Gallic acid was used as the standard phenolic component. Gallic acid solutions were prepared at 20-40-6080-100 $\mu \mathrm{g} \mathrm{mL}^{-1} .5 \mathrm{~mL}$ of each of these solutions were taken. $0.5 \mathrm{~mL}$ of Folin-Ciocalteu reagent and 5 $\mathrm{mL}$ of $7 \% \mathrm{Na}_{2} \mathrm{CO}_{3}$ solution were added to the gallic acid solution, respectively. The prepared mixture was stirred for 1 hour at room temperature in a shaker, then the absorbance of the spectrophotometer was measured at $760 \mathrm{~nm}$ against a blank sample of $\mathrm{MeOH}$ in place of the gallic acid. $0.2 \mathrm{mg} \mathrm{mL}^{-1}$ stock solutions were prepared from the methanolic extracts of the different parts of Geranium ibericum. As in the preparation of the standard graphic, $5 \mathrm{~mL}$ of methanolic extract was taken into the test tubes. $0.5 \mathrm{~mL}$ of Folin-Ciocalteu reagent and $5 \mathrm{~mL}$ of $7 \% \mathrm{Na}_{2} \mathrm{CO}_{3}$ solution were added, respectively. After mixing of the mixtures in the shaker for 1 hour, the readings of the absorbances against the blank solution at $760 \mathrm{~nm}$ were carried out. The results were expressed as $\mathrm{mg}$ gallic acid/g dried sample (dry weight: dw) (Kähkönen et al.,1999; Gezen, 2018). 


\section{Determination of Antioxidant Activity Using the 2,2-Diphenyl-1-picrylhydrazyl (DPPH) Radical Scavenging Activity Method}

DPPH free radical scavenging activity was performed according to the method of Zhang et al. (Zhang et al., 2009). BHT and $\alpha$-tocopherol were used as standard. $1 \mathrm{mM} \mathrm{DPPH}$ solution was used for analysis. The methanolic extracts of plant parts solutions prepared at 20-40-60-80-100-120-140 $\mu \mathrm{g}$ $\mathrm{mL}^{-1}$ were transferred to the test tubes with a total volume of $4 \mathrm{~mL} .1 \mathrm{~mL}$ of a DPPH solution was added. The mixture was stirred for 30 minutes at room temperature in a shaker and readings of absorbances against the blank solution containing $\mathrm{MeOH}$ instead of extract solution at $517 \mathrm{~nm}$ in spectrophotometer were performed. Each assay was carried out in triplicate. The percentage of the inhibition of DPPH radical was calculated using the following formula 1:

$$
\left.\% \text { Inhibition }=\left[\left(\mathrm{A}_{\text {control }}-\mathrm{A}_{\text {test }}\right) / \mathrm{A}_{\text {control }}\right] \times 100 \quad \text { (Formula 1. }\right)
$$

$\mathrm{A}_{\text {control: }}$ The absorbance value of the control value without extract sample.

$A_{\text {test: }}$ Absorbance value of sample that contains extract.

Antioxidant activities of test compounds or extracts were expressed as $\mathrm{IC}_{50}$, defined as the concentration of the test material required to decrease the initial DPPH concentration by $50 \%$ (Erkan et al., 2008; El-Hashash et al., 2010; Akar et al., 2017).

\section{Determination of Antioxidant Activity Using the ABTS Free Radical Scavenging Method}

ABTS free radical scavenging activity was performed according to the method of Re et al. (Re et al., 1999). BHT and $\alpha$-toc were used as standard. $7 \mathrm{mM}$ ABTS stock solution was used for analysis. The methanolic extracts of plant parts solutions prepared at 20-40-60-80-100-120-140 $\mu \mathrm{g} \mathrm{mL}^{-1}$ were transferred to the test tubes with a total volume of $4 \mathrm{~mL} .1 \mathrm{~mL}$ of a ABTS solution was added. The mixture was stirred for 30 minutes at room temperature in a shaker and readings of the absorbances against the blank solution using $\mathrm{MeOH}$ instead of sample at $734 \mathrm{~nm}$ in spectrophotometer were performed. The percentage of inhibition of $\mathrm{ABTS}^{\cdot+}$ was calculated using the following formula 1:

$$
\% \text { Inhibition }=\left[\left(\mathrm{A}_{\text {control }}-\mathrm{A}_{\text {test }}\right) / \mathrm{A}_{\text {control }}\right] \times 100 \text { (Formula 1.) }
$$

$\mathrm{A}_{\text {control: }}$ The absorbance value of the control without extract sample.

Atest: Absorbance value of the sample with extract.

Antioxidant activities of test compounds or extracts were expressed as $\mathrm{IC}_{50}$, defined as the concentration of the test material required to cause a $50 \%$ decrease in initial $\mathrm{ABTS}^{\cdot+}$ concentration.

\section{Statistical Analysis}

The experiments were carried out in triplicate and results are given as the mean \pm standard deviation. Statistical analyses were conducted with SPSS 22.0 version (IBM Corp. 2013). The differences among plant parts for total phenolic contents DPPH and ABTS free radical scavenging activities $\left(\mathrm{IC}_{50}\right)$ capacity were determined by one-way ANOVA test. 


\section{RESULTS AND DISCUSSION}

\section{Total Phenolic Content}

The amount of the total phenolic compound in the plant extracts was calculated as the Gallic acid equivalent (GAE) with the formula obtained from the standard graph (R2: 0.9996). The Gallic acid standard graphic prepared for this purpose is shown in Figure 1.

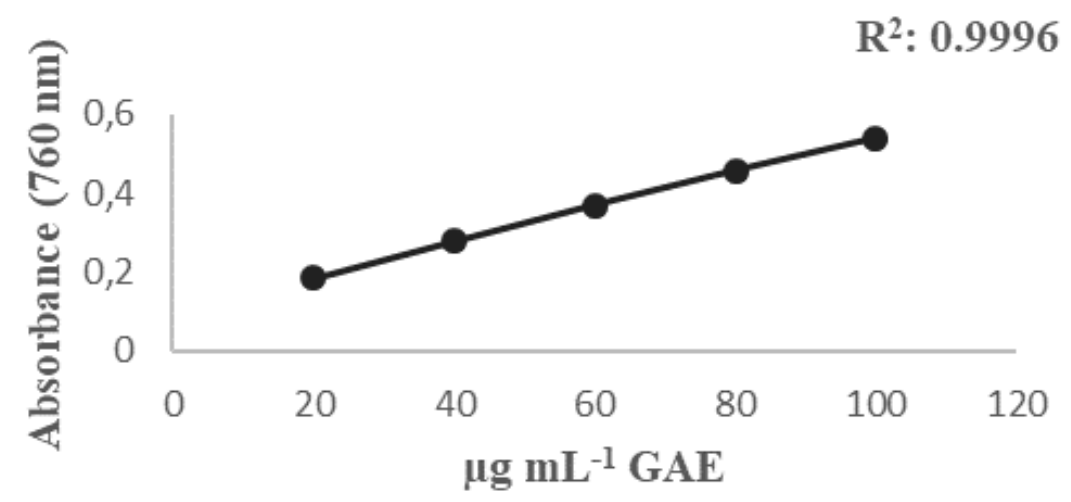

Figure 1: Standard curve of Gallic acid

The Gallic acid equivalents of G. ibericum subsp. jubatum parts extracts prepared by soxhlet extraction to determine the total phenolic content are shown below in Table 1. The highest phenolic content was observed for the root with $229.09 \pm 0.40 \mathrm{mg} \mathrm{GAE} \mathrm{g}^{-1} \mathrm{dw}$.

Table 1. Statistically interpretation of the total phenolic contents by the one-way ANOVA test. Different letters indicate the significant differences among the parts of G.ibericum at a 0.05 level using Tukey's HSD test.

\begin{tabular}{lcccc}
\hline Plant parts & Stem & Root & Flower & Leaf \\
\hline Total Phenolic Contents $\left(\mathbf{m g ~ G A E ~}^{-\mathbf{1}} \mathbf{d w}\right)$ & $98.00 \pm 4.78 \mathrm{a}$ & $229.09 \pm 1.35 \mathrm{c}$ & $193.84 \pm 0.20 \mathrm{c}$ & $226.30 \pm 0.90 \mathrm{~b}$ \\
Significance & 0.000 & 0.000 & 0.000 & 0.000 \\
\hline
\end{tabular}

According to the total phenolic results, the total phenolic content of the extracts of the four different parts were determined as follows: root $>$ leaf $>$ flower $>$ stem with $229.09 \pm 0.40,226.38 \pm 1.25$, $193.96 \pm 0.80,100.72 \pm 1.44 \mathrm{mg} \mathrm{GAE} \mathrm{g}^{-1} \mathrm{dw}$ respectively (Table 1).

\section{Free Radical Scavenging Activity}

The results of the DPPH and ABTS radical scavenging activity values were converted to $\mathrm{IC}_{50}$ and then evaluated (Figure 2.) (El-Hashash et al., 2010; Akar et al., 2017).
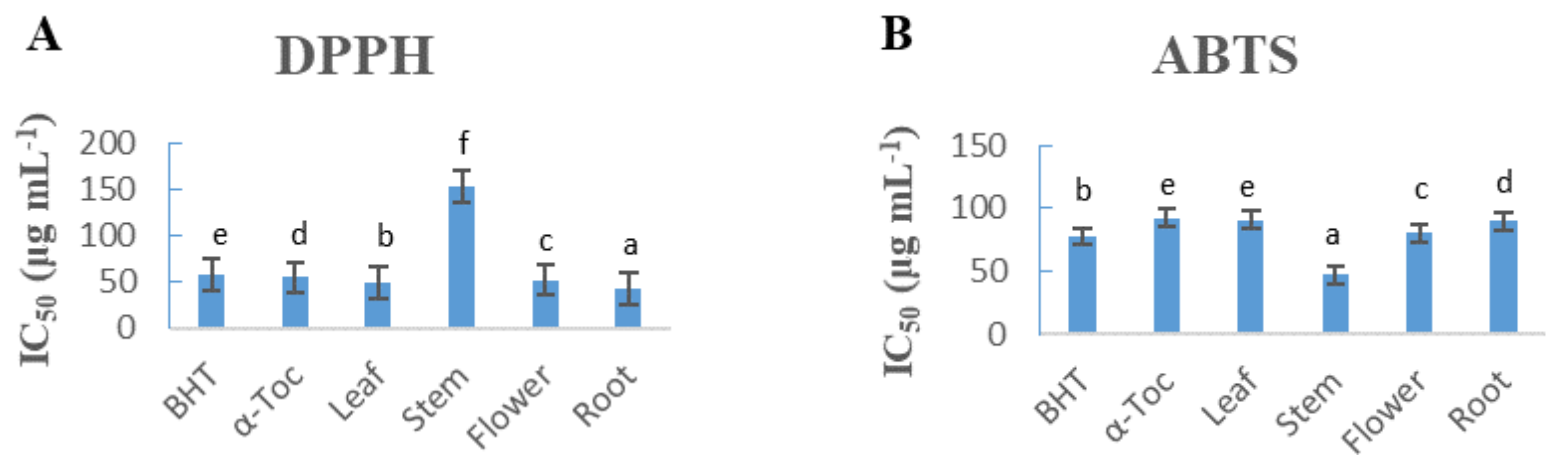

Figure 2. A-) Comparison of DPPH free radical scavenging activities ( $\left.\mathrm{IC}_{50}\right)$ of different parts of G.ibericum with BHT and $\alpha$-tocopherol. B-) Comparison of ABTS free radical scavenging activities ( $\left.\mathrm{IC}_{50}\right)$ of different parts of $G$. ibericum with BHT and $\alpha$-tocopherol 
According to the Figure 2, the total antioxidant activities of the extracts of the four different parts were as follows: root>leaf > flower >stem with $\mathrm{IC}_{50} 43.33,49.86,52.58$ and $152.44 \mu \mathrm{g} \mathrm{mL} \mathrm{m}^{-1}$, respectively. For the DPPH analysis, when the results were evaluated, the antioxidant activities of the root, leaf, and flower parts were higher than those of the BHT and $\alpha$-tocopherol (Figure 2 and Table 2).

According to the ABTS analysis, the total antioxidant capacity of the extracts of the four different parts was as follows: stem>flower>root>leaf with $\mathrm{IC}_{50} 47.24,80.19,89.47$, and $90.93 \mu \mathrm{g} \mathrm{mL}$ 1 , respectively. For the ABTS analysis, the antioxidant activities of the stem and flower parts were higher than the synthetic antioxidants BHT and $\alpha$-tocopherol (Figure 2 and Table 2).

Table 2. Free radical scavenging activity and statistically significant differences among the different parts of G. ibericum, $\alpha$-Toc and BHT values using one-way ANOVA. Different letters indicate the significant differences among the parts of G.ibericum at a 0.05 level using Tukey's HSD test.

\begin{tabular}{lccccccc}
\hline & \multicolumn{7}{c}{ Plant Parts } \\
\hline & Stem & Flower & Root & Leaf & BHT & $\boldsymbol{\alpha}$-Toc & Significance \\
\hline DPPH FRSA IC $_{50}\left(\mu \mathrm{g} \mathrm{mL}^{-1}\right)$ & $152.44 \pm 0.00 \mathrm{f}$ & $52.02 \pm 1.06 \mathrm{c}$ & $43.33 \pm 0.00 \mathrm{a}$ & $49.081 \pm 0.79 \mathrm{~b}$ & $57.00 \pm 0.82 \mathrm{e}$ & $55.00 \pm 0.48 \mathrm{~d}$ & 0.000 \\
ABTS FRSA IC $_{50}\left(\mu \mathrm{g} \mathrm{mL}^{-1}\right)$ & $47.18 \pm 0.10 \mathrm{a}$ & $80.44 \pm 0.45 \mathrm{c}$ & $88.84 \pm 1.09 \mathrm{~d}$ & $90.58 \pm 0.60 \mathrm{e}$ & $77.55 \pm 0.37 \mathrm{~b}$ & $92.10 \pm 0.00 \mathrm{e}$ & 0.000 \\
\hline FRSA: Free Radical Scavenging Activity & & & & &
\end{tabular}

The methods of ABTS and DPPH, which are used in this study, are the most popular two methods based on the colorimetric method for the determination of the antioxidant capacity of plant extracts. Different methods were used in different analysis to evaluate the total antioxidant capacity. There are differences in the antioxidant capacity of the G.ibericum subsp. jubatum extracts between the ABTS and DPPH methods. According to Shalaby and Shanab (2013), it can be said that one of the reasons is the solvent used in the extraction. As the polarity of the solvent changes, so does the content of the extract. The ABTS method has the extra flexibility in that it can be used at different pH levels (unlike DPPH, which is sensitive to acidic $\mathrm{pH}$ ) and thus is useful when studying the effect of $\mathrm{pH}$ on antioxidant activity of various compounds (Shalaby and Shanab, 2013). According to this information, it can be concluded that if the extraction solvent is changed, different results will be obtained in terms of antioxidant capacity of Geranium ibericum parts.

In light of the results, G. ibericum subsp. jubatum has been determined to be a very high source of antioxidant (Figure 2). It was collected from 2509.53 meters at Eğribel Pass. Due to the thinning of the atmosphere as the sea level increases, the plant is exposed to more ultraviolet light and produces more antioxidants in the defense mechanism (Martz et al., 2010). There are many studies that support the increase of total phenolic content in proportion to altitude (Wang et al., 2017). In a study published by Taremi et al. in 2015, the phenolic content of extracts of Marrubium astracanicum L. collected from different altitude increased as the altitude increased (Taremi et al., 2015).

\section{CONCLUSION}

It can be said that the phenolic compounds are higher in the roots than other parts, and this may be related to larger stiffness, low tissue flexibility and consequently lignification and resistance structures which constitute physical obstacles to soil pathogens (Sakihama et al., 2002; Dores et.al, 2014).

The present study is the first work performed on G. ibericum subsp. jubatum to evaluate the antioxidant capacity of different parts of plant. 


\section{ACKNOWLEDGEMENTS}

This paper includes some of the results of Gezen's master thesis. In order to collect endemic G.ibericum subsp. jubatum specimens, permission was obtained from The Ministry of Forestry and Water Affairs of the General Directorate of Nature Conservation and National Parks dated 03.01.2018 and numbered 72784983-488.04-3238.

\section{REFERENCES}

Aedo C, Garcia MA, Alarcon ML, Aldasoro JJ, Navarro C, 2005. Taxonomic Revision of Geranium subsect Mediterranea (Geraniaceae). Systematic Botany, 32(1): pp. 93-128.

Ahmed E, Arshad M, Khan MZ, Amjad MS, Sadaf HM, Riaz I, Sabir S, Nabila A and Sabaoon, 2017. Secondary Metabolites and Their Multidimensional Prospective in Plant Life. Journal of Pharmacognosy and Phytochemistry, 6(2): 205-214.

Akar Z, Küçük M, Doğan H, 2017. A new colorimetric DPPH• scavenging activity method with no need for a spectrophotometer applied on synthetic and natural antioxidants and medicinal herbs. Journal of Enzyme Inhibition and Medicinal Chemistry, Vol.32, No.1, 640-647.

Aksoy L, Kolay E, Ağılönü Y, Arslan Z, Kargığlu M, 2013. Free Radical Scavenging Activity, Total Phenolic Content, Total Antioxidant Status, and Total Oxidant Status of Endemic Thermopsis turcica. King Saud University Saudi Journal of Biological Sciences, 20: 235-239.

Aliyu BA, İbrahim AM, Musa MA, Musa OA, Kiplimo JJ. and Oyevale OA, 2013. Free Radical Scavenging and Total Antioxidant Capacity of Root Extracts of Anchomanes difformis Engl.(Araceae). Acta Poloniae Pharmaceutica-Drug Research, Vol. 70 No.1 pp. 115-121.

Arumugam R, Kirkan B, Sarikurkcu C, 2019. Phenolic Profile, Antioxidant and Enzyme Inhibitory Potential of Methanolic Extracts From Different Parts of Astragalus ponticus Pall. South African Journal of Botany, 120: 268-273.

Azwanida NN, 2015. A Review on the Extraction Methods Use in Medicinal Plants, Principle, Strength and Limitation. Medicinal \& Aromatic Plants, Volume 4, Issue 3, 1000196.

Chou H-J, Kuo J-T, and Lin E-S, 2009. Comparative Antioxidant Properties of Water Extracts from Different Parts of Beefsteak Plant (Perilla frutescens). Journal of Food and Drug Analysis, Vol. 17, No. 6, Pages 489-496.

Dai J, and Mumper JR, 2010. Plant Phenolics: Extraction, Analysis and Their Antioxidant and Anticancer Properties. Molecules, 15: 7313-7352.

Do DQ, Angkawijaya EA, Tran-Nguyen PL, Huynh HL, Soetaredjo EF, Ismadji S, Ju YH, 2014. Effect of extraction solvent on total phenol content, total flavonoid content, and antioxidant activity of Limnophila aromatica. Journal of food and drug analysis, 22: 296-302.

Dores GR R, Guimarães SF, Braga TV, Fonseca CM M, Martins PM, Ferreira TC, 2014. Phenolic compounds, flavonoids and antioxidant activity of leaves, flowers and roots of white-weed. Horticultura Brasileira, v. 32, n. 4, 486-490.

El-Hashash MM, Abdel-Gawad MM, El-Sayed MM, Sabry AW, Abdel-Hameed ESS, Abdel-Lateef EES, 2010. Antioxidant properties of methanolic extracts of the leaves of seven Egyptian Cassia species. Acta Pharmaceutica, 60, 361-367.

Erkan N, Ayranc1 G, Ayranc1 E, 2008. Antioxidant activities of rosemary (Rosmarinus officinalis L.) extract, blackseed (Nigella sativa L.) essential oil, carnosic acid, rosmarinic acid and sesamol. Food Chemistry, 110: 76-82.

Gezen SE, 2018. Determination of Antioxidant Capacities Of Some Endemic Species which spread in Alpine Region of Giresun Mountains, Giresun University, Institute of Science, Master Thesis (Printed).

Harborne JB, Williams CA, 2002. Phytochemistry of the genus Geranium, in: Lis-Balchin, M. (Ed.), Geranium and Pelargonium - The genera Geranium and Pelargonium. Taylor \& Francis, pp. 20-29, London-England.

Hüseyinoğlu R, Yalçın E, Macar O, 2017. Flora of Alpine Grasslands of The Eğribel Pass in the Giresun Mountains (Turkey). Biological Diversity and Conservation, 10-1, 6-17.

IBM Corp. 2013. Released: IBM Statistics for Windows, Version 22, Armonk, NY: IBM Corp. 
Kähkönen MP, Hopia AI, Heikki JV, Rauha JP, Pihlaja K, Kujala TS, Heinonen M, 1999. Antioxidant Activity of Plant Extracts Containing Phenolic Compounds. Journal of Agriculture and Food Chemistry, 47: 3954-3962.

Kahriman N, Tosun G, Genç H, Yaylı N, 2010. Comparative essential oil analysis of Geranium sylvaticum extracted by hydrodistillation and microwave distillation. Turkish Journal of Chemistry, 34, 969-976.

Kasangana BP, Haddad SP, Stevanovic T, 2015. Study of Polyphenol Content and Antioxidant Capacity of Myrianthus arboreus (Cecropiaceae) Root Bark Extracts. Antioxidants, 4: 410-426.

Kulisic T, Radonic A, Katalinic V, Milosa M, 2004. Use of different methods for testing antioxidative activity of oregano essential oil, analytical, nutritional and clinical methods. Food Chemistry, 85, 633-640.

Kumar S, 2011. Free Radicals and Antioxidants: Human and Food System. Advance in Applied Science Research, 2 (1):129-135.

Leucuta S, Vlase L, Gocan S, Radu L, Fodorea C, 2005. Determination of Phenolic Compounds from Geranium sanguineum by HPLC. Journal of Liquid Chromatography\&Related Technologies. 28: 3109-3117.

Mahdi-Pour B, Jothy L S, Latha YL, Chen Y, Sasidharan S, 2012. Antioxidant Activity of Methanol Extracts of Different Parts of Lantana camara. Asian Pacific Journal of Tropical Biomedicine, 2(12): 960-965.

Martz F, Jaakola L, Julkunen-Tiitto R, Stark S, 2010. Phenolic composition and antioxidant capacity of bilberry (Vaccinium myrtillus) leaves in northern Europe following foliar development and along environmental gradients. Journal of Chemical Ecology, 36, 9: 1017-1028.

Mojzer BE, Maša HK, Škerget M, Knez Ž, and Bren U, 2016. Polyphenols: Extraction Methods, Antioxidative Action, Bioavailability and Anticarcinogenic Effects. Molecules, 21: 901.

Proestos C, Lytoudi K, Mavromelanidou KO, Zoumpoulakis P, Sinanoglou JV, 2013. Antioxidant Capacity of Selected Plant Extracts and Their Essential Oils. Antioxidants, 2: 11-22.

Sakihama Y, Cohen MF, Grace SC, Yamasaki H, 2002. Plant phenolic antioxidant and prooxidant activities: phenolics-induced oxidative damage mediated by metals in plants. Toxicology, 177: 67-80.

Savc1 G, 2015. Anatomical, morphological and palynological characteristics of some Geranium 1. (Geraniaceae) species which spread in Hatay, Mustafa Kemal University, Institue of Science, Master Thesis (Printed).

Serkedjieva J, 1996. A polyphenolic extract from Geranium sanguineum L. inhibits influenza virus protein expression. Phytotherapy Research, 10: 441-443.

Shalaby AE, and Shanab MMS, 2013. Comparision of DPPH and ABTS Assays for Determining Antioxidant Potential of water and methanol extracts of Spirulna platensis. Indian Journal Geo-Marine Sciences, Vol. 42(5): 556-564.

Siddiqui WM, Prasad K, Bansal V, 2017. Plant Secondary Metabolites, Three-Volume Set. CRC Press, chapter 7.

Taremi F, Rowshan V, Shirzadi MH, 2015. Effects of altitude on total phenolic and polyphenol content of Marrubium astracanicum L. Extracts. International Research Journal of Applied and Basic Sciences, Vol., 9 (1), 113-116.

Wang X, Pengfei L, Wang F, Fu B, He F, Zhao M, 2017. Influence of altitudinal and latitudinal variation on the composition and antioxidant activity of polyphenols in Nicotiana tabacum L. Leaf. Emirates Journal of Food and Agriculture, 29(5): 359-366.

Zeljkovića Ć, Tanb K, Siljak-Yakovlevc S, and Maksimovićd M, 2017. Essential Oil Profile, Phenolic Content and Antioxidant Activity of Geranium kikianum. Natural Product Communications, Vol. 12 (2), 273-276.

Zhang Z, Liao L, Moore J, Wu T, Wang Z, 2009. Antioxidant Phenolic Compounds From Walnut Kernels (Juglans regia L.). Food Chemistry, 113: 160-165. 